\title{
Peripheral blood endotoxin levels are not associated with small intestinal bacterial overgrowth in nonalcoholic fatty liver disease without cirrhosis
}

\author{
Vivian Mota GUIMARÃES ${ }^{1,2}$, Virgínia Nascimento SANTOS ${ }^{2}$, Patrícia Souza de Almeida BORGES ${ }^{3}$, \\ João Luiz Rodrigues DE FARIAS², Penelope GRILLO² and Edison Roberto PARISE²
}

Received: 25 June 2020

Accepted: 26 August 2020

\begin{abstract}
Background - Nonalcoholic fatty liver disease (NAFLD) is one of the most common forms of chronic liver disease worldwide. Approximately $20 \%$ of individuals with NAFLD develop nonalcoholic steatohepatitis (NASH), which is associated with increased risk of cirrhosis, portal hypertension, and hepatocellular carcinoma. Intestinal microflora, including small intestinal bacterial overgrowth (SIBO), appear to play an important role in the pathogenesis of the disease, as demonstrated in several clinical and experimental studies, by altering intestinal permeability and allowing bacterial endotoxins to enter the circulation. Objective - To determine the relationship between SIBO and endotoxin serum levels with clinical, laboratory, and histopathological aspects of NAFLD and the relationship between SIBO and endotoxin serum levels before and after antibiotic therapy. Methods Adult patients with a histological diagnosis of NAFLD, without cirrhosis were included. A comprehensive biochemistry panel, lactulose breath test (for diagnosis of SIBO), and serum endotoxin measurement (chromogenic LAL assay) were performed. SIBO was treated with metronidazole $250 \mathrm{mg}$ q8h for 10 days and refractory cases were given ciprofloxacin $500 \mathrm{mg} \mathrm{q12h}$ for 10 days. Results - Overall, 42 patients with a histopathological diagnosis of NAFLD were examined. The prevalence of SIBO was $26.2 \%$. Comparison of demographic and biochemical parameters between patients with SIBO and those without SIBO revealed no statistically significant differences, except for use of proton pump inhibitors, which was significantly more frequent in patients with positive breath testing. The presence of SIBO was also associated with greater severity of hepatocellular ballooning on liver biopsy. Although the sample, as a whole, have elevated circulating endotoxin levels, we found no significant differences in this parameter between the groups with and without SIBO. Endotoxin values before and after antibiotic treatment did not differ, even on paired analysis, suggesting absence of any relationship between these factors. Serum endotoxin levels were inversely correlated with HDL levels, and directly correlated with triglyceride levels. Conclusion - Serum endotoxin levels did not differ between patients with and without SIBO, nor did these levels change after antibacterial therapy, virtually ruling out the possibility that elevated endotoxinemia in non-cirrhotic patients with NAFLD is associated with SIBO. Presence of SIBO was associated with greater severity of ballooning degeneration on liver biopsy, but not with a significantly higher prevalence of NASH. Additional studies are needed to evaluate the reproducibility and importance of this finding in patients with NAFLD and SIBO.
\end{abstract}

HEADINGS - Endotoxins. Gastrointestinal microbiome. Fatty liver. Non-alcoholic fatty liver disease.

\section{INTRODUCTION}

Nonalcoholic fatty liver disease (NAFLD) or, as recently suggested, Metabolic Dysfunction-Associated Fatty Liver Disease (MAFLD) is one of the most common forms of chronic liver disease worldwide. Approximately $20 \%$ of individuals with NAFLD develop nonalcoholic steatohepatitis (NASH), which can lead to cirrhosis, portal hypertension, and hepatocellular carcinoma ${ }^{(1)}$.

The pathogenesis of NAFLD/NASH is still unclear, but evidence suggests that disease progression depends on interactions between genetic and environmental factors ${ }^{(2-5)}$. Among environmental factors, changes in intestinal microflora, including small intestinal bacterial overgrowth (SIBO), appear to play a role in the pathogenesis of the disease, as demonstrated in several clinical and experimental studies ${ }^{(2,3,6-8)}$. By altering intestinal permeability, SIBO would allow bacterial endotoxins to enter the circulation and, within the liver, activate mediators leading to increased levels of proinflammatory cytokines, especially TNF- $\alpha$; this, in turn, would result in liver injury and promote disease progression ${ }^{(2,9,10)}$. This phenomenon might be demonstrated by an increase in circulating endotoxin levels in patients with NAFLD ${ }^{(11,12)}$.

The present study was designed to ascertain whether a relationship exists between SIBO and peripheral blood endotoxin levels before and after antibiotic treatment, as well as to compare clinical, laboratory, and histopathological aspects of NAFLD with serum endotoxin levels and presence of IBS, in patients with NAFLD.

Declared conflict of interest of all authors: none

Disclosure of funding: no funding received

${ }^{1}$ Universidade de Taubaté, Medicina, Taubaté, SP, Brasil. ${ }^{2}$ Unifesp, Medicina, São Paulo, SP, Brasil. ${ }^{3}$ Universidade Federal de Goiás, Faculdade de Medicina, Departamento de Gastroenterologia e Hepatologia, Goiânia, GO, Brasil.

Corresponding author: Vivian Mota Guimarães. E-mail: vivimotagui81@gmail.com 


\section{METHODS}

Adult outpatients with a histological diagnosis of NAFLD were included. Patients diagnosed with liver cirrhosis, other concomitant liver disease, positive HIV serology, antibiotic use in the preceding 30 days, history of abdominal surgery with intestinal resection, chronic renal failure, clinically decompensated type 2 diabetes mellitus (T2DM) (glycated hemoglobin [A1c] $>7 \%$ ), daily alcohol intake $\geq 40 \mathrm{~g}$ for men or $\geq 20 \mathrm{~g}$ for women, clinically decompensated thyroid, respiratory, or cardiac disease, and recent use of nonsteroidal anti-inflammatory drugs were deemed ineligible.

Anthropometric measurements (body mass index [BMI] and waist circumference) were obtained from all patients. Peripheral blood samples were collected after a 12-hour fast for measurement of serum liver enzyme activity (AST, ALT, FA, GGT), total bilirubin, ferritin, plasma glucose, A1c, TSH, albumin, platelet count, total cholesterol, HDL cholesterol, and triglycerides. Serum insulin levels were quantitated by chemiluminescence (PerkinElmer BR-CS) and used to calculate the HOMA-IR (Homeostatic Model Assessment Equation), with a cutoff point of 2.5 for insulin resistance (IR) $)^{(13,14)}$. The metabolic syndrome was diagnosed according to the Adult Treatment Panel III (ATP III) criteria ${ }^{(15)}$.

Formalin-fixed biopsy fragments, stained with hematoxylineosin, reticulin, and Masson's trichrome, were analyzed according to the criteria proposed by Kleiner et al. $(2005)^{(16)}$.

Serum endotoxin measurement was performed by a chromogenic Limulus Amebocyte Lysate (LAL) assay with the QCL-1000 TM LAL Endpoint Assay (Lonza, New Jersey, USA) commercial analysis kit, on sera previously stored at $-70^{\circ} \mathrm{C}$.

Diagnosis of SIBO (before and after antibiotic therapy) was established through the lactulose breath test, performed in a Gastro + Gastrolyzer ${ }^{\circledR}$ device (Bedfont), using the criteria proposed by Romagnuolo et al. (2002) (17).

Patients diagnosed with SIBO were treated with metronidazole $250 \mathrm{mg}$ q $8 \mathrm{~h}$ for 10 days; refractory cases were given ciprofloxacin $500 \mathrm{mg}$ q12h for 10 days $^{(18,19)}$.

Statistical analyses were performed in IBM SPSS Statistics for Windows, Version 10 (Chicago, IL, USA). Student's $t$-test and the Mann-Whitney $U$ test were used for between-group comparisons of continuous and non-continuous variables respectively, as well as the chi-square and Fisher's exact tests, as appropriate. Comparison of peripheral blood endotoxemia values before and after treatment of SIBO was done by a paired $t$-test. Pearson's coefficient was calculated to evaluate the correlation between serum endotoxin levels and laboratorial biochemical parameters. The null hypothesis was rejected at $P<0.05(\mathrm{a} £=5 \%)$.

The study protocol was approved by the Federal University of São Paulo Research Ethics Committee (CEP 1737/10).

\section{RESULTS}

Overall, 42 patients with a histopathological diagnosis of NAFLD were included in the sample. TABLE 1 lists the demographic and biochemical characteristics of these patients. The metabolic syndrome is one of the main factors implicated in the pathogenesis and progression of NAFLD. Accordingly, its prevalence in our patients was $73.8 \%$. Overall, $52 \%$ of patients had type 2 diabetes mellitus.

Histological examination of liver biopsy specimens revealed severe steatosis in most patients (grade 3 in 45.8\%), mild and mod-
TABLE 1. Demographic and biochemical characteristics of patients with non-alcoholic fatty liver disease (NAFLD) who underwent lactulose breath testing for diagnosis of small intestinal bacterial overgrowth (SIBO).

\begin{tabular}{lc}
\hline Parameters & $\mathrm{n}=42$ \\
\hline Gender (M/F) & $16 / 26$ \\
Age (years)* & $55.5 \pm 1.75$ \\
DM n (\%) & $22(52.3)$ \\
HOMA-IR * & $4.4 \pm 0.58$ \\
BMI $\left(\mathrm{kg} / \mathrm{m}^{2}\right)^{*}$ & $31.7 \pm 0.8$ \\
WC $(\mathrm{cm}) *$ & $102.2 \pm 1.41$ \\
MS $(\%)$ & 73.8 \\
AST $(\mathrm{UI} / \mathrm{L}) *$ & $35.7 \pm 2.22(1.02 \times \mathrm{ULN})$ \\
ALT $(\mathrm{UI} / \mathrm{L}) *$ & $47.0 \pm 3.95(1.34 \times \mathrm{ULN})$ \\
GGT(UI/L)* & $77.7 \pm 8.04(2.06 \times \mathrm{ULN})$ \\
HDL-cholesterol (mg/dL)* & $47.8 \pm 1.86$ \\
Triglycerides (mg/dL)* & $167.7 \pm 14.1$ \\
Ferritin (ng/mL)* & $243.0 \pm 32.2$ \\
\hline *Mean \pm standart deviation (SD). DM: diabetes mellitus; HOMA: homeostatic model asses- \\
sment; BMI: body mass index. WC: waist circumference; MS: metabolic syndrome; ULN: \\
upper limit of normality.
\end{tabular}

erate lobular inflammation in $61.9 \%$ and $23.8 \%$ respectively, and hepatocyte ballooning in approximately $85 \%$. Most patients had mild or absent fibrosis (33.3\% and $47.6 \%$ respectively). Moderate fibrosis was present in approximately $19 \%$, and none had cirrhosis.

A lactulose breath test was performed in all included patients and was positive for small intestinal bacterial overgrowth in 11 of 42 (overall prevalence, $26.2 \%$ ). The clinical symptoms most often associated with positive breath testing were flatulence and postprandial fullness.

Comparison of demographic (age and sex), clinical (prevalence of diagnosis of DM) and biochemical parameters (liver enzymes, ferritin, HDL cholesterol, triglycerides, glucose and insulin serum levels) between patients with SIBO and those without SIBO revealed no statistically significant differences, except for use of proton pump inhibitors (PPI), which was significantly more frequent in patients with positive breath testing (TABLE 2). The presence of SIBO was also associated with greater severity of hepatocellular ballooning on liver biopsy (TABLE 3). Among those with SIBO, more than $70 \%$ of the patients have NASH on liver biopsy but such difference did not reach statistical significance when compared with control group. (TABLE 3).

Although the circulating endotoxin levels were elevated in the entire cohort, we found no significant differences in this parameter between the groups with and without SIBO. Nine patients accepted treatment with metronidazole, and two required retreatments with ciprofloxacin. In all these patients, repeat breath testing after the first or second antibiotic treatment were negative for SIBO, and new peripheral blood samples were drawn for quantification of endotoxemia. Endotoxin values before and after antibiotic treatment did not differ, even on paired analysis, suggesting absence of any relationship between these factors in this cohort. (TABLE 4).

Serum endotoxin levels were inversely correlated with HDL cholesterol levels $(\mathrm{r}=-0.421, P=0.009)$, and directly correlated with triglyceride levels ( $\mathrm{r}=0.455, P=0.004)$ (data not shown). 
TABLE 2. Comparison of demographic and biochemical parameters between groups of patients with non-alcoholic fatty liver disease (NAFLD) with and without small intestinal bacterial overgrowth (SIBO) as detected by breath testing.

\begin{tabular}{lccc}
\hline \multirow{2}{*}{$\begin{array}{l}\text { Variables } \\
\text { (mean } \pm \text { SD) }\end{array}$} & $\begin{array}{c}\text { Bositive } \\
(11 / 42)\end{array}$ & $\begin{array}{c}\text { Negative } \\
(31 / 42)\end{array}$ & $P$ \\
\hline Gender (\%female) & $7 / 11(63 \%)$ & $12 / 31(61 \%)$ & 0.891 \\
Age (years) & $53.0 \pm 8.2$ & $56.4 \pm 12.3$ & 0.400 \\
BMI (Kg/m²) & $30.8 \pm 5.2$ & $31.8 \pm 5.2$ & 0.616 \\
WC (cm) & $103.6 \pm 9.9$ & $101.6 \pm 9.1$ & 0.533 \\
AST (IU/L) & $37.3 \pm 10.4$ & $35.1 \pm 15.7$ & 0.666 \\
ALT (IU/L) & $48.1 \pm 25.8$ & $46.6 \pm 25.9$ & 0.870 \\
GGT (IU/L) & $79.0 \pm 34.3$ & $76.2 \pm 57.6$ & 0.884 \\
Alkaline phosphatase (IU/L) & $81.7 \pm 21.1$ & $78.9 \pm 25.7$ & 0.746 \\
Glucose (mg/dL) & $104.5 \pm 17.9$ & $113.9 \pm 47.4$ & 0.530 \\
Insulin ( $\mu \mathrm{IU} / \mathrm{mL})$ & $17.9 \pm 10.2$ & $15.4 \pm 9.8$ & 0.477 \\
Triglycerides $(\mathrm{mg} / \mathrm{dL})$ & $166.8 \pm 49.2$ & $168.0 \pm 103.0$ & 0.971 \\
HDL-cholesterol(mg/dL) & $50.6 \pm 11.0$ & $46.8 \pm 12.5$ & 0.379 \\
Ferritin (ng/mL) & $246.5 \pm 218.8$ & $241.7 \pm 208.7$ & 0.948 \\
T2DM (\% cases) & $6 / 22(27 \%)$ & $5 / 20(25 \%)$ & 0.592 \\
PPI $\%$ cases) & $5 / 11(45 \%)$ & $3 / 31(9.7 \%)$ & $0.020 *$ \\
\hline
\end{tabular}

BMI: body mass index; WC: waist circumference; T2DM: type 2 diabetes mellitus; PPI: proton pump inhibitors. *Significant difference.

TABLE 3. Relationship between presence of SIBO (detected by lactulose breath testing) and the degree of histological findings on liver biopsy in patients with NAFLD.

\begin{tabular}{lcccc}
\hline & & $\begin{array}{c}\text { Non SIBO } \\
(\mathrm{n}=31)\end{array}$ & $\begin{array}{c}\text { SIBO } \\
(\mathrm{n}=11)\end{array}$ & $\boldsymbol{P}^{*}$ \\
\hline \multirow{2}{*}{ Fibrosis } & $0-1$ & $80 \%$ & $81 \%$ & 0.903 \\
\multirow{3}{*}{ Steatosis } & $2-4$ & $20 \%$ & $19 \%$ & \\
& $0-1$ & $22 \%$ & $28 \%$ & 0.754 \\
\multirow{3}{*}{ Ballooning } & $2-3$ & $78 \%$ & $72 \%$ & \\
\multirow{4}{*}{ Inflammation } & $0-1$ & $41 \%$ & $29 \%$ & 0.043 \\
& 2 & $64 \%$ & $71 \%$ & \\
\multirow{4}{*}{ NAS } & $0-1$ & $71 \%$ & $73 \%$ & 0.912 \\
& $2-3$ & $29 \%$ & $27 \%$ & \\
& $2-4$ & $38 \%$ & $28 \%$ & 0.493 \\
\hline
\end{tabular}

NAS: NAFLD activity score. *Chi-square test.

TABLE 4. Comparison of peripheral blood endotoxin levels between NAFLD patient groups with and without small intestinal bacterial overgrowth (SIBO) before and after antibiotic therapy and confirmation of negative breath test.

\begin{tabular}{|c|c|c|c|}
\hline \multirow[b]{2}{*}{ Breath Test } & \multicolumn{2}{|c|}{ Serum endotoxin level (EU/mL) } & \multirow[b]{2}{*}{$P^{*}$} \\
\hline & $\begin{array}{l}\text { Before treatment } \\
(\mathrm{n}=42)\end{array}$ & $\begin{array}{l}\text { After treatment } \\
(\mathrm{n}=9)\end{array}$ & \\
\hline Positive $(\mathrm{n}=11)$ & $3.2+0.23$ & $2.9+0.95$ & 0.929 \\
\hline Negative $(n=31)$ & $2.8+0.18$ & & \\
\hline$P^{* *}$ & 0.357 & & \\
\hline
\end{tabular}

\section{DISCUSSION}

Several clinical and experimental studies conducted over the years have demonstrated the influence of the intestinal microbiota on the pathophysiology of obesity, insulin resistance, and $\operatorname{NAFLD}^{(2,3,6,20,21)}$.

The intestinal flora is believed to play a role in promoting steatohepatitis through increased hepatic exposure to endotoxins. Release of lipopolysaccharides (LPS) by Gram-negative bacteria and loss of intestinal barrier integrity result in increased endotoxin absorption into the portal circulation ${ }^{(3,10,22)}$. Toll-like receptors (TLRs), essential components of the immune system, are present on the surface of Kupffer cells and are capable of recognizing pathogen-associated molecular patterns (PAMPs), including LPS (endotoxin). Stimulation of these TLRs by PAMPs leads to the activation of nuclear factor kappa-B $(\mathrm{NF} x \mathrm{~B})$, resulting in the transcription of genes that encode inflammatory cytokines (especially TNF- $\alpha$ ), chemokines, and antimicrobial compounds ${ }^{(23)}$.

SIBO is a form of dysbiosis characterized by an increase in the number and/or type of bacteria present in the upper gastrointestinal $\operatorname{tract}^{(24)}$. The relationship between SIBO and NAFLD pathogenesis is based on the finding that intestinal-derived endotoxins are important cofactors in the development of alcoholic steatohepatitis and cirrhosis ${ }^{(25)}$, and on experimental studies demonstrating that SIBO alters intestinal permeability, leading to increased portal endotoxemia and, in a phenomenon mediated by release of TNF- $\alpha$ and other toxins, liver damage and activation of stellate cells, triggering steatohepatitis in genetically modified animals ${ }^{(2,26)}$. On the other hand, SIBO and increased intestinal permeability are more frequently observed in patients with NAFLD when compared to controls $^{(3,6)}$. Elevated peripheral blood endotoxin levels have also been observed in clinical trials of patients with NAFLD ${ }^{(11,25)}$.

While recent literature attests to the occurrence of SIBO at higher rates than control subjects among individuals with a host of underlying conditions, correlations with clinical features, such as nutritional status and outcomes are far from consistent ${ }^{(27)}$. The SIBO has even been linked with obesity. A recent meta-analysis found that the risk of SIBO was about two times higher among individuals with obesity compared to individuals without obesity, although the result did not reach statistical significance ${ }^{(28)}$.

In our study, we found a $26.2 \%$ prevalence of SIBO in the included patients with NAFLD. This prevalence has been quite variable in the literature, ranging from $17 \%$ to $60^{(3,9,21)}$. In 2016 , Fialho et al. ${ }^{(29)}$ conducted a multivariate analysis and found that SIBO was a risk factor for development of NAFLD, as were type 2 DM and obesity. Wigg et al. (2001) were the first to document this association. According to these authors, the main factor implicated in the higher prevalence of SIBO in patients with NASH as compared to controls was the presence of T2DM and glucose intolerance ${ }^{(6)}$. Microvascular complications of T2DM may predispose to SIBO as a result of decreased bowel transit time due to autonomic neuropathy. In the present study, although more than half of the included patients had type $2 \mathrm{DM}$, we found no relationship between T2DM and presence of SIBO. However, the non-eligibility of patients with Alc $>7 \%$ to the study may lead to the exclusion of those T2DM patients with greater impairment of intestinal motility.

Another factor that certainly influenced the prevalence of SIBO in our series was the exclusion of cirrhotic patients. Liver cirrhosis - and, especially, portal hypertension - have deleterious effects on 
intestinal motility, permeability, and microbiome. All these effects combine to result in an imbalance of the intestinal microflora and predispose to the development of $\mathrm{SIBO}^{(30-33)}$. Furthermore, the presence of portal hypertension leads to portal blood being shunted to the peripheral circulation, which is likely an additional determinant of serum endotoxemia. On the other hand, changes in gastrointestinal motility have been described in patients with NAFLD without cirrhosis ${ }^{(34)}$.

Gastric acid secretion is one of the major factors implicated in controlling intestinal microflora. Therefore, the profound gastric acid suppression induced by long term treatment with PPI might alter intestinal microflora thus giving rise to a number of problems including development of small intestinal bacterial overgrowth and increased susceptibility to gastrointestinal tract infections ${ }^{(24,35,36)}$. In our series, chronic use of PPIs was the only clinical factor clearly associated with presence of SIBO.

Regarding the association of SIBO with histopathological features of NAFLD, some studies have shown that the prevalence of SIBO increases significantly with the severity of steatosis, but is unrelated to the presence of NASH, lobular inflammation, or fibrosis ${ }^{(3,21)}$. In our study, we found no association between diagnosis of SIBO and severity of steatosis, but there was a significant increase in the degree of ballooning degeneration of hepatocytes in patients with positive breath test. Such association was not specifically evaluated in any of the previous studies which included histological examination of liver biopsy specimens in patients with SIBO. These studies focused on the severity of fibrosis, steatosis, inflammation, and, of course in the presence or absence of NASH on biopsy ${ }^{(3,6,11,12,21)}$. Hepatocyte ballooning in NAFLD is associated with alterations in the cytoskeleton and, possibly, in multiple organelles of liver cells ${ }^{(37,38)}$. It constitutes the main marker for histological diagnosis of $\mathrm{NASH}^{(39)}$ and, as such, is associated with disease progression ${ }^{(40,41)}$. Considering that the presence of ballooning degeneration is an essential condition for the histological diagnosis of NASH, it would be expected that patients with SIBO in this trial would have a significant increase in this histological diagnosis. In fact, having the NAS activity score higher or equal to five for the prediction of $\mathrm{NASH}^{(16)}$, this score was found in $71 \%$ of the SIBO patients against $62 \%$ in those with a negative lactulose breath test, but this difference was not statistically significant. Probably the best interpretation is that this finding was hindered by the small number of patients with SIBO in our sample. Thus, these histological findings warrant further exploration in other studies with larger series.

In parallel, the accuracy of hydrogen breath testing also needs to be discussed. There are major concerns about hydrogen breath testing examination where it might be difficult to exclude the presence of SIBO when the result is negative, since the sensitivity and specificity for breath test for this diagnosis was reported to be only $40 \%$ and $80 \%$, respectively ${ }^{(42)}$. Until now there is no standard cut off for duodenal or jejunal aspiration examination which has been for some authors as the best test to detect the intestinal bacterial proliferation $^{(42,43)}$. These considerations, however, does not invalidate the use of hydrogen breath test for diagnosis of SIBO, in addition, the finding of a negative repeat breath test after antibiotic treatment provides additional confirmation of the validity of the diagnosis.

Endotoxin has been suggested as a possible link between SIBO and elevated levels of proinflammatory cytokines, especially $\mathrm{TNF}-\alpha$, a known and important mediator of liver injury in NASH. High TNF levels in peripheral blood have been associated with increased inflammatory activity in tissue, and a progressive increase in serum TNF concentrations is observed as the severity of hepatocyte ballooning increases ${ }^{(2,9,44)}$. Other authors, however, have not confirmed this association ${ }^{(45)}$. Nevertheless, a study evaluating the expression of genes that control TNF-alpha expression in liver tissue found an association with plasma levels of lipopolysaccharidebinding protein ${ }^{(46)}$, which provides additional evidence.

Previous studies have shown that endotoxins derived from intestinal bacteria can play a significant role in the progression from simple steatosis to steatohepatitis ${ }^{(3,47)}$. Low levels of portal endotoxemia are sometimes detected in healthy individuals but are rarely accompanied by liver injury ${ }^{(48,49)}$. Although the levels of endotoxin required to cause consequences in the presence of NAFLD are unknown, it is well established that patients with hepatic steatosis are hyperresponsive to endotoxin levels that would otherwise be considered low. This is because these individuals overexpress CD14, a molecule that forms a complex (TLR-4/CD14) with the TLR-4 receptors present in Kupffer cells and subsequently activates the intracellular proinflammatory cascade via the NF- $x \mathrm{~B}$ pathway ${ }^{(47,50)}$. In 2016, Kapil et al. found higher gene expression of TLR4, CD14, and NF- $x$ B in the liver tissue of patients with NASH and SIBO, confirming the role of this condition in the pathogenesis of NAFLD ${ }^{(51)}$. These findings notwithstanding, the impact of increased serum endotoxin levels during progression to NASH remains controversial. Harte et al. (2010) and Wong et al. (2015) found high serum endotoxin levels in NAFLD patients compared to controls, but no significant differences between patients with steatosis, NASH, and cirrhosis ${ }^{(11,12)}$. Wigg et al. (2001) found no differences in serum endotoxin levels between controls and patients with $\mathrm{NASH}^{(6)}$, while Loguercio et al. (2004), using a qualitative method, failed to even find detectable levels of endotoxemia ${ }^{(52)}$. The lack of any correlation between serum endotoxin levels and severity of liver impairment was also reported in another study which analyzed the composition of the intestinal flora ${ }^{(8)}$. Thus, the question remains of whether serum endotoxin levels accurately reflect portal endotoxemia. Under normal conditions, endotoxins capable of crossing the intestinal barrier are promptly removed from the circulation by Kupffer cells in the liver. The presence of hepatocellular insufficiency or shunting due to portal hypertension would create the necessary conditions for an increase in systemic endotoxemia ${ }^{(11,53)}$. However, it has also been argued that chylomicrons may provide an avenue through which serum LPS levels increase regardless of the presence of hepatocellular dysfunction ${ }^{(11,54)}$.

To the best of our knowledge, this was the first study to analyze endotoxin levels before and after antibiotic treatment in noncirrhotic humans with NAFLD and SIBO. Corroborating the findings of Bode et al. ${ }^{(55)}$ in patients with alcoholic liver disease, we did not find any significant differences in endotoxin levels before and after antibiotic treatment and after conversion of lactulose breath test from positive to negative.

Among the biochemical parameters analyzed herein, serum endotoxin levels were not associated with presence of insulin resistance, but they did correlate with triglyceride and HDL cholesterol values (inversely with the latter). Correlations with these two parameters had already been reported in other studies of NAFLD patients which evaluated endotoxin concentrations ${ }^{(12,56,57)}$. In addition to being part of the metabolic syndrome, which was present in most of our patients, this correlation has been associated with the role played by these lipid components in the metabolism and transport of LPS molecules in the circulation ${ }^{(57-59)}$. 
Taken together, our data support the hypothesis peripheral blood endotoxemia in patients with NAFLD, without cirrhosis, and with SIBO does not reflect higher intestinal production of endotoxin. In addition to finding no differences in serum endotoxin levels between patients with and without SIBO, blood levels of endotoxin remained unchanged from baseline after resolution of SIBO. These data in no way contradict the possibility that the microbiota plays a role in liver injury; they merely suggest that, in non-cirrhotic NAFLD patients with preserved liver function, peripheral blood endotoxin levels do not reflect the portal endotoxemia described in experimental studies ${ }^{(2,6)}$.

Serum endotoxin levels did not differ between patients with and without SIBO, nor did these levels change after antibacterial therapy, virtually ruling out the possibility that endotoxemia is associated with SIBO. Presence of SIBO was associated with greater severity of ballooning degeneration on liver biopsy, but not with a significant higher prevalence of NASH. Additional studies are needed to evaluate the reproducibility and importance of these findings in patients with NAFLD and SIBO.

\section{Authors' contribution}

Guimarães VM: conceptualization, data curation, formal analysis, funding acquisition, investigation, project administration, resources, supervision, validation, visualization, writing - original draft, writing - review \& editing. Santos VN: data curation, investigation, writing - review, resources. Borges PSA: data curation, investigation, resources. de Farias JLR: data curation, investigation, resources. Grillo P: data curation, investigation, resources. Parise ER: conceptualization, data curation, formal analysis, methodology, funding acquisition, investigation, project administration, resources, supervision, validation, visualization, writing - original draft, writing - review \& editing.

\section{Orcid}

Vivian Mota Guimarães: 0000-0001-7839-997X.

Virgínia Nascimento Santos: 0000-0001-6574-5343.

Patrícia Souza de Almeida Borges: 0000-0001-9422-1135.

Joao Luiz Rodrigues de Farias: 0000-0001-8078-480X.

Penelope Grillo: 0000-0002-9182-8238.

Edison Roberto Parise: 0000-0003-4890-9259.

Guimarães VM, Santos VN, Borges PSA, de Farias JLR, Grillo P, Parise ER. Níveis de endotoxina no sangue periférico não estão relacionados ao supercrescimento bacteriano intestinal em portadores de doença hepática gordurosa não alcoólica sem cirrose. Arq Gastroenterol. 2020;57(4):471-6.

RESUMO - Contexto - A doença hepática gordurosa não alcoólica (DHGNA) é uma das doenças hepáticas crônicas mais comuns em todo o mundo. Aproximadamente 20\% dos indivíduos com DHGNA desenvolvem esteato-hepatite não alcoólica (EHNA) que está associada a maior risco de cirrose, hipertensão portal e/ou carcinoma hepatocelular. Alterações da microflora intestinal, incluindo o supercrescimento bacteriano intestinal (SBI), parecem ter um papel importante na patogênese da doença, como demonstrado em estudos clínicos e experimentais, pela alteração da permeabilidade intestinal e permitindo que endotoxinas bacterianas alcancem a circulação sanguínea. Objetivo - Determinar a relação entre o SBI e níveis de endotoxina sérica em pacientes não cirróticos com DHGNA, com os aspectos clínicos, laboratoriais e histopatológicos da doença e a relação entre SBI e níveis séricos de endotoxina antes e após tratamento com antibiótico. Métodos - Foram incluídos pacientes maiores de 18 anos e com diagnóstico histológico de DHGNA, sem cirrose. Foram realizados: avaliação bioquímica geral, teste do H2 expirado com lactulose para diagnóstico de SBI e dosagem de endotoxina sérica - ensaio cromogênico para LAL. Para o tratamento do SBI utilizamos o metronidazol $250 \mathrm{mg}$ de $8 / 8$ horas por 10 dias e para os casos de retratamento foi utilizado ciprofloxacino $500 \mathrm{mg}$ de 12/12 horas por 10 dias. Resultados - Incluímos 42 pacientes com diagnóstico histopatológico de DHGNA. A prevalência de SBI foi de 26,2\%. Quando comparamos o grupo dos pacientes com SBI com aquele sem SBI e analisamos suas variáveis demográficas e bioquímicas, não encontramos diferença estatisticamente significante entre elas, exceto pela utilização de inibidores de bomba de próton, que foi significantemente mais frequente nos pacientes com teste respiratório positivo. A presença de SBI também esteve associada à maior intensidade de balonização na biópsia hepática, quando comparados àqueles sem SBI. Embora o grupo como um todo apresentasse elevação dos níveis circulantes de endotoxinas, não pudemos encontrar diferenças estatísticas entre os grupos com e sem SBI. Os valores de endotoxinas pré e pós tratamento antibiótico não diferiram entre si, mesmo em análise pareada, sugerindo ausência de relação entre esses fatores. Os níveis de endotoxina sérica apresentaram correlação inversa com os níveis de HDL e correlação direta com os níveis de triglicerídeos. Conclusão - Níveis de endotoxinas séricas não diferiram entre os pacientes com e sem SBI, e que esses níveis não se modificaram após tratamento medicamentoso da proliferação bacteriana, praticamente excluindo a possibilidade de que os níveis elevados de endotoxemia estejam relacionados à SBI. A presença dessa proliferação bacteriana esteve associada à maior intensidade de balonização na biópsia hepática, mas não à maior prevalência de EHNA entre os portadores de SBI. Estudos complementares são necessários para avaliar a reprodutibilidade e a importância desse achado em portadores de DHGNA com SBI.

DESCRITORES - Endotoxinas. Microbioma gastrointestinal. Fígado gorduroso. Hepatopatia gordurosa não alcoólica.

\section{REFERENCES}

1. Younossi ZM, Koenig AB, Abdelatif D Fazel Y, Henry L, Wymer M. Global epidemiology of non-alcoholic fatty liver disease - meta-analytic assessment of prevalence, incidence and outcomes. Hepatology. 2016;64:73-84. doi: 10.1002/ hep. 28431 .

2. Yang SQ, Lin HZ, Lane MD, Lane MD, Clemens M, Diehl AM. Obesity increases sensitivity to endotoxin liver injury; implications for the pathogeneses of steatohepatitis. Proc Natl Acad Sci USA. 1997;94:2557-62.

3. Miele L, Valenza V, La Torre G, Montalto M, Cammarota G, Ricci R, et al. Increased intestinal permeability and tight junction alterations in nonalcoholic fatty disease. Hepatology. 2009;49:1877-87.
4. Veena J, Muragundla A, Sidgiddi S, Subramaniam S. Non Alcoholic fatty liver disease: need for a balanced nutritional source. Br J Nutr. 2014;112:1858-72.

5. Smallwood T, Allayee H, Bennett BJ. Choline metabolites: gene by diet interactions. Curr Opin Lipidol.. 2016;27:33-9.

6. Wigg AJ, Roberts-Tomson IC, Dymock RB, McCarthy PJ, Grose RH, Cummins AG. The role of small intestinal bacterial overgrowth, intestinal permeability, endotoxaemia, and tumor necrosis factor alpha in the pathogenesis of non-alcoholic steatohepatitis. Gut. 2001;48:206-11.

7. Shanab AA, Quigley EM. The role of gut microbiota in nonalcoholic fatty liver disease. Nat Rev Gastroenterol Hepatol. 2010;7:691-701. 
8. Yuan J, Baker SS, Liu W, Alkhouri R, Baker RD, Xie J, et al. Endotoxemia unrequired in the pathogenesis of pediatric nonalcoholic steatohepatitis. J Gastroenterol Hepatol. 2014;29:1292-8.

9. Wu WC, Zhao W, Li S. Small intestinal bacteria overgrowth decrease small intestinal motility in the rats. World J Gastroenterol. 2008;14:313-17.

10. Jiang W, Wu N, Wang X, Chi Y, Zhang Y, Qiu X, et al. Dysbiosis Gut Microbiota associated with Inflammation and Impaired Mucosal Immune Function in Intestine of Humans with Non-alcoholic Fatty Liver Disease. Scientific Reports 2015;5:8096.

11. Harte AL, Silva N, Creely SJ,Billyard T, Youssef-Elabd E, Tripathi G, et al Elevated endotoxin levels in non-alcoholic fatty liver disease. J Inflamm (Lond). 2010;7:1-10

12. Wong VW, Wong GL, Chan HY, Yeung DK, Chan RS, Chim AM, et al. Bacterial endotoxin and non-alcoholic fatty liver disease in general population: prospective cohort study. Alimentary Pharmacology. 2015; 42:731-40.

13. Matthews DR, Hosker JP, Turner RC, Naylor BA, Treacher DF, Turner RC. Homeostatic model assessment: insulin resistance and beta-cell funtion from fasting glucose and insulin concentrations in man. Diabetologia. 1985;28:412-19.

14. SalgadoALFA, CarvalhoL, OliveiraAC, SantosVN, VieiraJG, Parise ER. Insulin resistance index (HOMA-IR) in the differentiation of patients with non-alcoholic fatty liver disease and healthy individuals. Arq Gastroenterol. 2010;47:165-9.

15. Expert Panel on Detection Evaluation and Treatment of High Blood Cholesterol in Adults. Executive summary of the third report of the National Cholesterol Education Program (NCEP). JAMA. 2001;285:2486-97.

16. Kleiner DE, Brunt EM, VanNatta M, Behling C, Contos MJ, Cummings OW, et al Nonalcoholic Steatohepatites Clinical Research Network: design and validation of a histological scoring system for nonalcoholic fatty liver disease. Hepatology. 2005;41:1313-21.

17. Romagnuolo J, Dan Shiller MSC, Bailey R. Using breath test wisely in a gastroenterology practice: an evidence-based review of indications and pitfalls in interpretation. Am.J.Gastroenterol. 2002;97:1113-26.

18. Prado FC, Ramos J, Ribeiro do valle J (org). Atualização Terapeutica. 22nd ed São Paulo: Artes Médicas, 2005:p504.

19. Miszputen SJ. Guia de Medicina Ambulatorial e Hospitalar UNIFESP: Gastroenterologia. 2nd ed. São Paulo: Manole, 2007:p324.

20. Backhed F, Ding H, Wang T, Hooper LV, Koh GY, Nagy A. The gut microbiota as an environmental factor that regulates fat storage. Proc Natl Acad Sci USA. 2004;101:718-23.

21. Sabaté JM, Jouet P, Harnois F, Mechler C, Msika S, Grossin M. Higth Prevalence of Small Intestinal Bacterial Overgrowth in Patients with Morbid OBesitiy: A contributor to Severe Hepatic Steatosis. Obes Surg. 2008;18:371-7.

22. Bugianese E, Vanni E.The gut-liver Axis in nonalcoholic fatty liver disease: Another Pathway to insulin resistance? Hepatology. 2009; 49:1790-92.

23. Chassaing B, Etienne-Mesmin L, Gewirts AT. Microbiota-liver Axis in Hepatic Disease. Hepatology. 2014; 59:328-39.

24. Bures J, Cyrany J, Kohoutova D, Förstl M, Rejchrt S, Kvetina J, et al.Small intestinal bacterial overgrowth syndrome. World J Gastroenterol. 2010;16:2978-90.

25. Farhadi A, Gundlapalli S, Shaikh M, Frantzides C, Harrell L, Kwasny MM, et al. Susceptilbility to gut leakiness: a possible mechanism for endotoxaemia in non-alcoholic steatohepatitis. Liver Int. 2008:28;1026-33.

26. Brun P, Casaglioulo I, Di Leo V, Buda A, Pinzani M, Palù G, et al. Increase intestinal permeability in obese mice: new evidence in the pathogenesis of non-alcoholic steatohepatitis. Am J Physiol Gastrointest Liver Physiol. 2007;292:G518-25.

27. Quigley EM, Murray JA, Pimentel M, AGA Clinical Practice Update on Small Intestinal Bacterial Overgrowth: Expert Review, Gastroenterology, 2020. doi https://doi.org/10.1053/ j.gastro.2020.06.090.

28. Wijarnpreecha K, Werlang ME, Watthanasuntorn K, Panjawatanan P, Cheungpasitporn W, Gomez V, et al. Obesity and Risk of Small Intestine Bacteria Overgrowth: A Systematic Review and Meta-Analysis. Digestive Diseases and Sciences, 2019. https ://doi.org/10.1007/s1062 0-019-05887 -x

29. Fialho A, Fialho A, Thota P, McCullough AJ, Bo S. Small Intestinal Bacterial Overgrowth Is Associated with Non-Alcoholic Fatty Liver Disease. J Gastrointestin Liver Dis. 2016;25:159-65

30. Gunnarsdottir SA, Sadik R, Shev S, Simrén M, Sjövall H, Stotzer PO, et al. Small Intestinal Motility Disturbances and Bacterial Overgrowth in Patients With Liver Cirrhosis and Portal Hypertension Motility and Portal Hypertension in Cirrhosis Am J Gastroenterol. 2003;98:1362-70.

31. Garcia-Tsao G, Wiest R. Gut microflora in the pathogenesis of the complications of cirrhosis. Best Pract Res ClinGastroenterol. 2004;18:353-72.

32. Ghassemi S, Garcia-Tsao G. Prevention and treatment of infections in patient with cirrhosis. Best Pract Res Clin Gastroenterol. 2007;21:77-93.
33. Kalaitzakis E. Gastrointestinal dysfunction in liver cirrhosis. World J Gastroenterol 2014;28:1686-95.

34. Soza A, Riquelme A, González R, Alvarez M, Pérez-Ayuso RM, Glasinovic $\mathrm{JC}$, et al. Increased orocecal transit time in patients with nonalcoholic fatty liver disease. Dig. Dis. Sci. 2005;50:1136-40.

35. Lo WK, Chan WW. Proton pump inhibitor use and the risk of small intestina bacterial overgrowth: a meta-analysis. Clin Gastroenterol Hepatol. 2013;11:483-90.

36. Su T, Lai S, Lee A, He X, Chen S. Meta-analysis: proton pump inhibitors moderately increase the risk of small intestinal bacterial overgrowth. J Gastroenterol. 2018;53:27-36.

37. Lackner C, Gogg-Kamerer M, Zatloukal K, Stumptner C, Brunt EM, Denk H Ballooned hepatocytes in steatohepatitis: The value of keratin immunohistochemistry for diagnosis. J Hepatol. 2008;48:821-8.

38. Caldwell S, Ikura Y, Dias D, Isomoto K, Yabu A, Moskaluk C,Pramoonjago P, Simmons W, Scruggs H, Rosenbaum N, Wilkinson T,Toms P, Argo CK, Al-Osaim AMS, Redick JA. Hepatocellular ballooning in NASH. J Hepatol. 2010;53:719-23.

39. Brunt EM. Non-alcoholic steatohepatitis: definition and pathology. Sem Liv Dis 2001;21:3-16.

40. Matteoni CA, Younossi ZM, Gramlich T, Boparai N, Liu YC, McCullough AJ. Nonalcoholic fatty liver disease: A spectrum of clinical and pathological severity. Gastroenterol. 1999;116:1413-19.

41. Rafiq N, Bai C, Fang Y, Srishord M, McCullough A, Gramlich T, et al. Long-term follow-up of patients with nonalcoholic fatty liver. Clin Gastroenterol Hepatol. 2009;7:234.

42. Saad RJ, Chey WD. Breath Testing for Small Intestinal Bacterial Overgrowth Maximizing Test Accuracy. Clin Gastroenterol Hepatol. 2014;12:1964-72.

43. Ghoshal UC. How to interpret hydrogen breath test. J Neurogastroenterol Motil 2011;17:312-7

44. Manco M, Marcelini M, Giannone G, Nobili V. Correlation of serun TNF-alpha levels and histologic liver injury scores in Nonalcoholic fatty liver disease. Am J ClinPathol. 2007; 127:954-60

45. Hui JM, Hodge A, Farrell GC, Kench JG, Kriketos A, George J. Beyond insulin resistance in NASH: TNF-alpha or adiponectin? Hepatology. 2004;40:46-54.

46. Ruiz AG, Casafont F, Crespo J, Cayón A, Mayorga M, Estebanez A, et al Lipopolysaccharide-binding protein plasma levels and liver TNF-alpha gene expression in obese patients: evidence for the potential role of endotoxin in the pathogenesis of non-alcoholic steatohepatitis. Obes Surg. 2007:17:1374-80.

47. Imajo K, Fujita K, Yoneda M, Nozaki Y, Ogawa Y, Shinohara Y, et al. Hyperresponsivity to Low-Dose Endotoxin during Progression to Nonalcoholic Steatohepatitis Is Regulated by Leptin-Mediated Signaling. Cell Metabolism. 2012:4:44 PM-54.

48. Triger DR, Boyer TD, Levin J. Portal and systemic bacteraemia and endotoxaemia in liver disease. Gut. 1978;19:935-39.

49. Jacob AI, Goldberg PK, Levin J. Endotoxin and bacteraemia in portal blood Gastoenterology. 1977;72:1268-70.

50. Shanab AA, Scully P, Crosbie O, Buckley M, O'Mahony L, Shanahan F, et al Small Intestinal bacterial overgrowth in nonalcoholic setatohepatitis: association with toll-like receptor 4 expression and plasma levels of interleukin 8. Dig Dis Sci. 2011;56:1524-34

51. Kapil S, Duseja A, Sharma BK, Singla B, Chakraborti A, Das A, et al. Small intestinal bacterial overgrowth and toll-like receptor signaling in patients with non-alcoholic fatty liver disease. J Gastroenterol Hepatol. 2016; 31:213-21.

52. Loguercio C, De Simone T, D’Auria MV, de Sio I, Federico A, Tuccillo C, et al. Non-alcoholic fatty liver disease: a multicentre clinical study by the Italian Association for the Study of the Liver. Dig. Liver Dis. 2004;36:398-405.

53. Munford RS. Endotoxin(s) and the liver. Gastroenterology. 1978:75:532-5.

54. Ghoshal S, Witta J, Zhong J, de Villiers W, Eckhardt E. Chylomicrons promote intestinal absorption of lipopolysaccharides. J Lipid Res. 2009;50:90-7.

55. Bode C, Schäfer C, Fukui H, Bode JC. Effect of Treatment with Paramomycin on Endotoxemia in Patients with Alcoholic Liver Desease. A double Blind, Placebo-Controlled Trial. Alcohol Clin Exp Res. 1997;21:1367-73.

56. Lassenius M, Pietiläinen KH, Kaartinen K, Pussinen PJ, Syrjänen J, Forsblom C, et al. Bacterial Endotoxin Activity in Human Serun Is Associated With Dyslipidemia, Insulin Resistance, Obesity and Chronic Inflamation. Diabetes Care. 2011;35:1809-15.

57. Miller MA, McTernan PG, Harte AL, Silva NF, Strazzullo P, Alberti KG, et al. Ethnic and sex differences in circulating endotoxin levels: A novel marker of atherosclerotic and cardiovascular risk in a British multi-ethnic population Atherosclerosis. 2009;203:494-502.

58. Wendel M, Paul R, Heller AR. Lipoproteins in inflammation and sepsis. II Clinica Aspects. Intensive Care Med. 2007;33:25-35.

59. Feingold KR, Shinenaga JK, Kazemi MR, McDonald CM, Patzek SM, Cross AS, et al. Mechanisms of triglyderide accumulation in activated macrophages. J Leukoc Biol. 2012;92:829-39. 